JURNAL PENDIDIKAN, p-ISSN 2715-095X, e-ISSN 2686-5041

Volume 30, No.1, Maret 2021 (81-94)

Online: http://journal.univetbantara.ac.id/index.php/jp

\title{
Penggunakan Model Pembelajaran Kooperatif Sebagai Strategi Pembelajaran Pada Mata Pelajaran Bahasa Inggris Tingkat SMA
}

\author{
Sumardi \\ Guru SMA Negeri 1 Gemolong, E-mail: sumardigemolong@yahoo.co.id
}

\begin{abstract}
Abstrak: Dunia pembelajaran dituntut selalu berkreasi dan berinovasi sepanjang jaman. Guru salah satu mesin penggerak di dalamnya. Oleh karena itu, guru harus mampu mengadakan perubahan dan perkembangan dalam malaksanakan tugasnya. Kemampuan mengadakan perubahan dalam pembelajaran termasuk strategi untuk mewujudkan tujuan pembelajaran yang sudah ditentukan. Mengapa guru harus memiliki strategi pembelajaran? Strategi pembelajaran merupakan serangkaian cara untuk mewujudkan tujuan pembelajaran termasuk penggunaan model pembelajaran inovatif. Model pembelajaran inovatif yang dilakukan oleh guru harus berpusat pada kegiatan peserta didik, menarik dan menyenaangkan. Disamping itu pembelajaran harus sesuai dengan karakter dan lingkungan peserta didik sehingga pembelajaran bisa menggugah minat dan semangat peserta didik. Untuk mewujudkan hal tersebut, guru harus menguasai jenis-jenis model pembelejaran dan langkah-langkahnya. Dengan menguasai model pembelajaran secara baik, guru dapat memilih jenis model pembelajaran mana yang sesuai dengan materi, karakter peserta didik dan lingkungannya. Penulis sering menggunakan model pembelajaran yang berbeda-beda tergantung jenis materinya dan hasilnya sangat signifikan. Setiap model pembelajaran mempunyai kelebihan dan kelemahan. Pilihlah jenis model pembelajaran yang sesuai dengan materi, peserta didik, lingkungan dan tujuan pembelajaran.
\end{abstract}

Kata-kata Kunci: Model-model pembelajaran, Strategi pembelajaran, Pembelajaran kooperatif

\section{The Use Of Kooperative Learning Models as Learning Strategy In English Subject of Senior High School}

\begin{abstract}
Sumardi
Teacher of Senior High School1Gemolong,Email:sumardigemolong@yahoo.co.id

Abstract: Education world is always demanded to be craetive and inovative in teaching. Teacher must be able to make change and development in teaching. The ability to make the change and dovelopment in teaching learning process as a strategy to creat the result which has been decided. Why must the teacher have accurate learning strategies? Learning strategy is a set of activities to creat the purpose of learning including the use of inovative learning model. The learning model done by the teacher must be to students activity centered, interesting and fun. Beside that teaching learning process must be suitable with students' character and their environment so it can encourage the students' interest and spirit. To creat those, the teacher must achieve well to the kinds of learning model and the syntaxes. By echieving and understanding the kinds og learning model well, the teacher can choose the learning model suitable with the material, students' character, and their environment. Writer often uses the different learning models depend on the material. The result of using the learning models are significant. Every leaning model has strengths and weaknesses. Choose a cooperative learning model which is suitable with the material, students, environment condition and learning purpose.
\end{abstract}

DOI: https://doi.org/10.32585/jp.v30i1.1202 
Key words: Learning models, Learning Strategy, Cooperative learning

\section{Pendahuluan}

Dalam proses pembelajaran yang dilakukan oleh guru, terutama guru mata pelajaran bahasa Inggris, peserta didik mengalami berbagai macam kendala yang dihadapi. Masalah tersebut bisa menyebabkan proses pembelajaran kurang menarik dan menyenangkan sehingga akan berdampak dengan tujuan pembelajaran itu sendiri. Peserta didik merasa kesulitan dalam mengikuti proses pembelajaran yang disampaikan oleh gurunya. Dampak yang sangat dirasakan oleh perserta didik pada saat mereka mengerjakan evaluasi, mereka tidak bisa memahami soal dan menjawab dengan benar, sehingga hasilnya jauh dari KKM yang sudah ditentukan. Hal tersebut bisa diakibatkan dari faktor internal guru sendiri. Kekurangan tersebut misalnya; 1) kurangnya kompetensi profesional, 2) kurang memahami karakter peserta didik, 3) kurang kreatif, 4) kurang menguasai metode, 5) kurang menguasai model pembelajaran dan lain sebagainya. Guru harus menghilangkan mindset berpikir pada sebagaian peserta didik bahwa pelajaran bahasa Inggris itu sulit dan tidak menaarik. Bagaimana cara membuat pembelajaran bahasa Inggris itu menarik, menyenangkan, diminati dan kondusif bagi peserta didik.Guru harus mampu menciptakan aktivitas proses pembelajaran dengan suasana menyenangkan bagi mereka. Salah satu cara yang harus dilakukan oleh seorang guru harus mampu memilih model-model pembelajaran yang sesuai dengan karakter peserta didik jaman sekarang (milenial) terutama bagi peserta didik jenjang SMA. Pemilihan model pembelajaran yang tepat dan menyenangkanbisa meningkatkanminat dan gairah belajar bahasa Inggris bagi peserta didik.Keterampilan seorang guru untuk menciptakan aktivitas interaksi belajar yang menarik dan menyenangkan dan juga disesuaikan dengan lingkungan dan kebutuhan peserta didik bisa meningkatkan konsepberfikir, bahasa, sikap, perilaku dan karakter lainya. Pembelajaran bahasa asing, termasuk bahasa Inggris, guru harus mampu mempertimbangkan kebutuhan dan karakter peserta didik agar pembelajarannya berhasi. Hal ini senada dengan teori yang diungkapkan oleh Piaget (1963: 34) "young learner's foundation of thinking, language, vision, attitudes, and other characteristics develop through the direct interaction with things and environment around them. In this case, foreign language learning must consider the needs and characteristics of young learners in order to be successful inlearning.

Dalam pembelajaran, seorang guru harus memiliki visi dan tujuan yang ingin dicapai pada peserta didik. Visi dan tujuan tersebut harus dikonsep sedemikian rupa sebagai dasar untuk memilih model pembelajaran yang cocok, efektif dan praktis. Dalam mengonsep visi dan tujuan harus mempertimbangkan kondisi lingkungan, kebutuhan dan karakter peserta didik. Model pembelajaran yang cocok dengan kondisi dan dunia peserta didik dapat mendorong minat bagi peserta didik dan juga dapat menghasilkan tujuan pembelajaran yang maksimal. Sebaliknya model dan metode pembelajaran yang kurang sesuai dengan kondisi peserta didik akan menghasilkan dampak negatif seperti peserta didik menjadi bosan, tidak tertarik, tidak fokus, mengganggu temanya (jika pembelajaran tatap muka di kelas), akan ditinggalkan (jika pembelajaran PJJ) dan hasilnya kurang memuaskan. Dampak negatif tersebut disebabkan pembelajaran yang tidak menyenangkan sehingga mereka tidak berminat.

Minat dalam pembelajaran salah satu faktor internal peserta didik yang sangat penting. Minat bisa mendorong mereka dengan sendirinya selalu memperhatikan pembelajaran dari guru sehingga mereka merasa nyaman dan senang dalam belajar. 
Menurut Sudarsono dalam Waryana (2020:58) menuliskan bahwa minat merupakan sikap ketertarikan atau sepenuhnya terlibat dengan suatu kegiatan karena menyadari pentingnya atau bernilaianya kegiatan tersebut. Jadi dalam pembelajaran, peserta didik akan berminat dengan sendirinya terhadap pembelajaran yang disampaikan oleh gurunya jika pembelajaran itu menarik dan menyenangkan. Sehingga mereka bisa mengikuti proses pembelajaran dengan senang dan juga bisa memahaminya dengan jelas serta bisa mengerjakan evaluasi yang diberikan oleh gurunya. Hal tersebut salah satunya disebabkan kemampuan seorang guru dalam memilih jenis model pembelajaran. Kemampuan memilih jenis model pembelajaran merupakan salah satu keterampilan yang harus dimiliki oleh guru. Ketepatan memilih model pembelajaran akan menentukan hasil pembelajaran. Disamping itu, ketepatan memilih model pembelajaran juga mengakibatkan pembelajaran yang lebih hidup, menyenangkan dan berbobot atau memiliki dampak pembelajaran kualitas tinggi. Keterampilan memilih jenis model pembelajaran salah satu tugas guru dalam menentukan strategi pembelajaran. Strategi pembelajaran yang tepat akan membawa peserta didik pada kegiatan pembelajaran yang tepat pula. Strategi pembelajaran merupakan prosedur bebarapa elemen yang disusun secara sistematis untuk mencapai tujuan pembelajaran tertentu secara efektif dan efisien. Strategi pembelajaran merupakan rangkaian kegiatan dan cara pengkondisian materi pelajaran, peserta didik, media, metode, model pembelajaran, bahan dan waktu yang digunakan ketika dalam proses pembelajaran untuk mencapai tujuan pembelajaran. Jadi bagi guru menentukan strategi pembelajaran sangat penting untuk dipahami karena akan memiliki dampak yang besar terhadap sebuah proses pembelajaran. Dalam menentukan strategi pembelajaran seorang guru harus mengaitkan dengan pembelajaran inovatif.Pembelajaran inovatif merupakan pembelajaran yang lebih bersifat students centered. Artinya pembelajaran yang lebih memberikan peluang kepada peserta didik untuk mengkonstruksi pengetahuan secara mandiri dan berkolaborasi dengan teman sebaya. Pembelajaran inovatif juga merupakanpembelajaran paradigma konstruktivistik yang membantu peserta didik untuk menginternalisasi, membentuk kembali, atau mentransformasi informasi baru. Pembelajaran konstruktivisme tersebut memotivasi kepada peserta didik dalam pencapaian pemahaman pembelajaran secara mendalam. Peranan guru dalam pembelajaran knstruktivisme sebagai manager, mediator, expert learner and creator. Creator merupakan peranan guru yang paling sulit dibanding yang lainya karena peranan creator meminta guru berinisiatif dan berinovatif dalam tugas pembelajarannya, termasuk kreatif memilih jenis model pembelajaran. Model pembelajaran merupakan kerangka konseptual yang menggambarkan prosedur yang sistematis dalam mengorganisasikan pengalaman belajar dengan kenyataan sekarang untuk mencapai tujuan pembelajaran. Guru diharapakan mampu memilih jenis model pembelajaran yang sesuai dengan karakter dan lingkungan peserta didik yang diampunya.

\section{Jenis Model Pembelajaran dan Penerapannya}

Model pembelajaran yang baik adalah model pembelajaran yang memiliki mudah diterapkan oleh dunia pembelajar dan memiliki dampak positif dan signifikan terhadap hasil pembelajaran. Kedua, pilihlah model pembelajaran yang sesuai dengan materi, karakter peserta didik dan ligkungannya. Ketiga memilih model pembelajaran yang relatif praktis, efektif dan efisien. Keempat, pilihlah jenis model pembelajaran yang kelemahannya relatif kecil karena tiap-tiap model pembelajaran memiliki kekurangan dan kelebihan masing-masing. Disamping hal tersebut, sebelum menentukan model 
pembelajaran mana yang akan digunakan, guru harus memahami langkah-langkah dari masing-masing model pembelajaran.

Pertama model pembelajaran kooperatif Jigsaw. Model pembelajaran ini merupakan pembelajaran kooperatif di mana guru harus membentuk peserta didik menjadi beberapa kelompok kecil. Setiap kelompok terdiri dari $4-6$ peserta didik yang berasal dari tingkatan kemampuan dan jenis kelamin yang berbeda-beda. Tujuannya agar proses pembelajaran berjalan dengan memaksimalkan kerja sama, kolaboratif, fektif dan efisien. Oleh karena itu dalam Jigsaw ada istilah kelompok asal dan kelompok ahli. Hal ini mempunyai dampak positif bagi perkembangan dan keterampilan berpikir bagi peserta didik. Pembelajaran Jigsaw juga jenis pembelajaran yang menyenangkan dan saling menghargai pendapat rekan kelompok karena penyelesaian suatu masalah harus diselesaikan secara bersama-sama. Peserta didik yang lebih cepat bisa membimbing rekanrekan yang berpikir lebih lambat. Setiap anggota harus ikut aktif dan proaktif dalam penyelesaian materi yang ada pada kelompoknya dengan baik karena meraka harus menyampaikan materi tersebut di kelompok lain. Jigsaw dideskripsikan sebagai strategi pembelajaran pendewasaan peserta didik melalui kelompok ahli. Setelah kelas dibentuk oleh guru menjadi beberapa kelompok asal. Kemudian kelompok asal menyusun kelompok ahli yang terdiri dari perwakilan kelompok asal untuk mendiskusikan materi atau memecahkan masalah tertentu. Setelah kelompok ahli selesai melaksanakan tugas maka kelompok ahli kembali kepada kelompok asal, untuk menerangkan hasil perkerjaan yang diperoleh di dalam kelompok ahli tadi. Prosedur penerapan model pembelajaran kooperatif Jigsaw adalah pertama; 1) guru membentuk kelompok asal yang beranggotankan 4 sampai 6 peserta didik, 2) guru membagikan materi atau permasalahan yang berkaitan dengan materi yang diajarkan, 3) setiap anggota kelompok memahami materi atau persoalan yang diberikan guru. Kedua; 1) guru dan kelompok asal membentuk kelompok ahli, 2) mengelompokkan peserta didik yang mendapat tugas yang sama, dimasukkan kedalam satu kelompok, 3) mulai bekerja sama antar kelompok ahli di dalam kelompoknya, 4) sampaikan bahwa semua anggota kelompok ahli harus memahami materi karena mereka harus bisa menyampaikan atau menjelaskan di kelompok asal, 5) perwakilan kelompok kembali kelompok asal jika waktu diskusi sudah selesai, 6) guru memberi kesempatan kepada masing-masing menyampaikan hasil dari tugas di kelompok ahli, 7) guru beserta peserta didik mengadakan rfleksi dan evaluasi setelah masing-masing kelompok selesai melaporkan hasilnya. Kelebihan model pembelajaran kooperatif Jigsaw adalah; 1) meningkatkan hubungan baik antara peserta didik yang memiliki kemampuan berbeda, 2) berlatih membimbing teman sejawat, 3) saling menghormati, menghargai dan menerima perbedaa, 4) menghilangkan sifat sombong dan egois, 5) mendorong motivasi belajar dan bersaing yang sehat, 6) meningkatkan pemahaman materi dengan kritis. Sedangnkan kelemahanny adalah; 1) guru harus selalu memonetor dan memfasilitasi kelompok agar tidak pasif, 2) membutuhkan waktu relatif lama, baik dalam persiapan maupun dalam pembelajaran. Model pembelajaran kooperatif Jigsaw sangat cocok digunakan untuk pembelajaran bahasa Inggris dengan materi tenses, seperti; simple present tense, present continuous tense, present future tense, present perfect tense, past tanse, past continuous tense, dan lainnya. Pentingnya strategi yang tepat dalam pembelajaran tenses karena setiap genre base text memiliki ciri kebahasaan yang berbeda-beda. Peserta didik akan sulit berbahasa Inggris baik secara tulis maupun lesan jika mereka tidak memiliki kemampuan tenses yang cukup. Dalam penerapan pembelajaran Jigsaw melatih para peserta didik untuk bekerja sama di dalam kelompok ahli jika mereka belum memahami pola struktur dan 
penggunaan masing-masing tenses.

Tabel 1. Tahapan dan ilustrasi model pembelajaran Jigsaw menurut (Elliot Aronson: 1997)

\begin{tabular}{|c|l|c|c|}
\hline Tahap & \multicolumn{1}{|c|}{ Kegiatan } \\
\hline 1 & $\begin{array}{l}\text { Siswa berkumpul di kelompok asal } \\
\text { dan masing-masing mendapatkan } \\
\text { tugas yang berbeda }\end{array}$ \\
\hline 2 & $\begin{array}{l}\text { Setiap siswa dengan bagian tugas } \\
\text { yelomg sama berkumpul dalam } \\
\text { materi yang diberikan }\end{array}$ \\
\hline 3 & $\begin{array}{l}\text { Siswa kembali ke kelompok asal } \\
\text { untuk mengajarkan berbagai materi } \\
\text { sesuai tugasnya masing-masing } \\
\text { kepada seluruh anggota kelompok } \\
\text { asal }\end{array}$ \\
\hline 5 & $\begin{array}{l}\text { Diskusi kelas antar kelompok yang } \\
\text { dipimpin oleh guru kelas }\end{array}$ \\
\hline 6 & Melaksanakan tes individu & \\
\hline Pemberian penghargaan kelompok
\end{tabular}

Di samping itu, Jigsaw juga mendorong dan meningkatkan mental psikologi terutama peserta didik yang merasa minder, rendah diri dan takut sebelum masuk ke kelompok ahli karena pada kelompok ahli mereka harus proaktif dan responsif dalam mendiskusikan pola struktur kalimat yang benar beserta penggunaan dari masing-masing tenses. Hal ini positif bagi meraka karena mereka sudah melatih keberanian dan percaya diri sebelum kembali ke kelompok asal. Setelah kembali ke kelompok asal, mereka harus menyampaikan, menjelaskan atau melaporkan hasil diskusi di kelompok ahli. Inilah salah satu keunikan model pembelajaran Jigsaw bahwa peserta didik lain merasa nyaman, santai, alami dan juga bisa paham terhadap materi penggunaan tenses dari rekannya sendiri. Mereka tidak merasa spaneng karena bisa kolaboratif bisa bebas bertanya dengan menggunakan bahasa mereka sendiri.

Kedua, model pembelajaran kooperatif Group to Group Exchange. Model pembelajaran Group to Group Exchange merupakan model pembelajaran pertukaran antar kelompok dalam memberikan tugas yang berbeda dari kelompok lain. Dalam pembelajaran Group to Group Exchange, guru memberikan tugas berbeda kepada kelompok yang berbeda. Kelompok yang sudah menyelesaikan tugasnya di kelompok masing-masing, kelompok tersebut harus memilih wakilnya untuk menyampaikan hasil di kelompok lain. Dalam hal ini setiap kelompok harus aktif berpartisipasi agar ia paham dengan tugas yang didiskusikan karena sewaktu-waktu ia ditunjuk sebagai wakil untuk menyampaikan hasil di kelompok lain, ia sudah siap dengan baik. Langkah-langkah model pembelajaran Group to Group Exchange antara lain; 1) guru memilihkan topik yang berbeda antar kelompok agar menghasilkan konsep gagasan dan pendapat berbeda, 2) guru membagi kelas ke dalam kelompok sesuai jumlah tugas yang sudah disiapkan, 3) guru menjelaskan teknik permainan pembelajaran Group to Group Exchange, 4) membagikan tugas yang berbeda ke setiap 
kelompok, 5) kelompok mengerjakan atau mendiskusikan tugas sesuai dengan waktunya, 6) guru memanggil perwakilan setiap kelompok untuk menyampaikan hasilnya di kelompok lain, 7) guru memberikan kesempatan kelompok lain untuk menanggapi dan bertanya setelah presentasi usai, 8) guru memberikan refleksi, apresiasi, motivasi dan evaluasi jika perwakilan kelompok sudah selesai presentasi semua. Pembelajaran Group to Group Exchange juga memiliki kelebihan dan kekurangan. Kelebihan pembelajaran Group to Group Exchange adalah; 1) peserta didik lebih termotivasi dan aktif bertanya dan memberi pendapatnya dalam kelompok, 2) pemahaman materi atau jawaban bisa lebih mendalam dan berkualitas karena dikerjakan secara kolaborasi, 3) peserta didik kelompok lain juga lebih releks, senang dan bisa memahami materi karena dijelaskan dengan bahasa teman sendiri, 4) setiap peserta didik berusaha menguasai materi karena ia akan mewakili kelompok untuk presentasi di kelompok lain, 5) menumbuh kembangkan rasa sosial dan kerja sama serta menghargai yang pendapat orang lain. Sedangkan kelemahannya adalah; 1) pembelajaran membutuhkan waktu relatif lama, 2) peserta didik merasa takut, malu dan was-was jika ditinjuk sebagai wakil kelompok untuk presentasi di kelompok lain, 3) mempersiapkan mental dan keberanian untuk menjadi wakil yang harus mempresentasikan hasil kelompok ke kelompok lain. Model pembelajaran Group to Group Exchange sangat cocok dalam pembelajaran bahasa Inggris materi teks discussion. Teks discussion merupakan teks yang menyampaikan suatu isu yang mengundang pendapat-pendapat yang berbeda. Perbedaan pandangan tersebut dilandasi dari masing-masing alasan yang kuat. Pembelajaran Group to Group Exchange sangant mendorong peserta didik dalam mendiskusikan suatu masalah. Mereka biasanya sangat antusias berdiskusi dari suatu masalah yang berbeda dari masalah antar kelompok. Pembelajaran materi teks dicussion membuat peserta didik cenderung ke kelompok pro dan kontra terhadap suatu isu atau topik. Masing-masing kelompok, baik kelompok pro maupun kontra terhadap masalah, mereka akan mengumpulkan data sebanyak-banyaknya yang digunakan sebagai data pendukung argumenya pada saat presentasi. Mereka tidak akan malu jika argumennya lengkap, mendasar, dan berkualitas karena dari masing-masing kelompok akan menilainya. Dengan menggunakan model pembelajaran ini, peserta didik merasa antusias, nyaman, alami, senang, berkolaboratif dan berkompetitif dengan sehat karena mereka belajar dengan rekan sejawat sendiri.

Ketiga, model pembelajaran kooperatif Talking Chips. Pembelajaran Talking Chips merupakan pembelajaran kooperatif yang dilaksanakan dalam kelompok. Setiap kelompok beranggotakan 4 sampai 6 peserta didik. Setiap peserta didik dalam kelompok diberi sejumlah kartu bicara (talking chips). Fungsi kartu ini bicara sebagai bukti bahwa ia sudah berpendapat atau menjawab, lalu kartu ditaruh di meja. Setiap anggota selesai menjawab, ia harus menaruh satu kartu di meja. Model pembelajaran menggunakan istilah Talking Chips ini awalnya dikembangkan oleh Spancer Khan. Sedangkan di Indonesi sering disebut model pembelajaran Kancing Gemerincing sebagaimana disampaikan oleh (Anita, 2008: 63). Alasan pembelajar sering menggunakan manik-manik kancing baju atau manik-manik lainya karena mudah didapatkan. Alasan lain manik-manik kancing baju murah dan warnanya menarik, sehingga bisa menambah suasana pembelajaran lebih ramai dan hidup.Model pembelajaran ini dipilih karena untuk meningkatkan motivasi peserta didik terutama mereka yang berpikir lambat. Kedua, untuk memotivasi keaktifan peserta didik yang merasa malu, minder atau takut salah berbahasa Inggris secara langsung. Model pembelajaran ini juga memberi manfaat bagi semua peserat didik, baik mereka yang berpikir cepat maupun berpikir lambat. Pembelajaran ini mendorong berkolaboratif antar 
peserta didik. Peserta didik tidak hanya menyelesaikan tugasnya sendiri akan tetapi mereka juga harus membantu rekan lainnya dalam kelompok yang mengalami kesulitan. Peserta didik yang tingkat tinggi akan bermanfaat bagi rekan yang membutuhkannya. Sedangkan yang berpikir lambat, mereka berani bertanya karena sesama rekannya. Langkah-langkah pembelajaran Talking Chips menurut Anita (2008: 64) adalah; 1) guru menjelaskan materi dan teknik cara bermain dengan pembelajaran Talking Chips, 2) guru memberi tugas sesuai materi, 3) guru menyiapkan sejumlah kancing baju atau kartu bicara, 4) guru membagikan sejumlah kacing baju kepada peserta didik tiap-tiap kelompok, 5) setiap peserta didik dari tiap-tiap kelompok berbicara atau menjawab dan menaruh kartu di meja dan jika kartu miliknya habis, ia tidak boleh menjawab sampai semua rekan anggota menghabiskan kartunya, 6) jika tugas belum selesai dan kartu semua sudah habis, maka kelompok mengambil kartu lagi jika waktunya masih. Kelebihan model pembelajaran Talking Chips adalah; 1) dengan kartu yang dipegang dapat meningkatkan motivasi keberanian, mental dan percaya diri karena harus berbicara atau menjawab, 2) setiap anggota memiliki hak yang sama karena membawa jumlah kartu yang sama, 3) masing-masing anggota lebih bertanggung jawab untuk menyelesaikan tugsnya, 4) peserta didik mendapatkan kepastian berbicara. Adapun kelemahan model pembelajaran Talking Chips adalah; 1) memerlukan waktu relatif lama untuk mempersiapkan kelas dan kelompok, 2) guru dituntut mengawasi dan memonetor keaktifan peserta didik terutama jika jumlah peserta didik cukup banyak, 3) guru harus berperan aktif sebagai fasilitator dalam proses pembelajaran. Model pembelajaran Talking Chips ini sangat cocok digunakan dalam pembelajaran bahasa Inggris dengan materi Short Function Text secara lesan, seperti expression of agrrement and disagreement, expression of praise, expression of opinion, expression of identity, expression of greeting dan lainnya. Short functional text tersebut menuntut peserta didik mampu menguasai materi secara lesan. Oleh karena itu, mereka harus mempunyai keberanian mental dalam berbicara bahasa Inggris. Dengan menggunakan model pembelajaran Talking Chips, mereka akan terdorong keberaniannya dalam berbicara karena mereka memegang kartu berbicara. Secara otomatis mereka berusaha mempersiapkan dan memberanikan diri untuk berbicara bahasa Inggris sesuai tugas yang diberikan.

Keempat, model pembelajaran kooperatif Discovery Learning. Model pembelajaran Discovery Learning pada dasarnya pembelajaran yang memberi kebebasan kepada peserta didik untuk bereksplorasi aktif dan proaktif untuk mencapai tujuan pembelajaran yang sudah ditentukan. Pembelajaran ini menuntut peserta didik memahami mampu konsep tertentu sampai bisa menarik simpulan. Budiningsih (2005: 43) menyampaikan bahwa model Discovery Learning adalah memahami konsep, arti, dan hubungan melalui proses intuitif untuk akhirnya kepada suatu kesimpulan. Pembelajaran ini bisa berjalan dengan baik apabila setiap peserta didik terlibat aktif langsung ke dalam proses kegiatan untuk menemukan konsep dan prinsip rasional dan logika. Pembelajaran Discovery Learning biasanya dilakukan dengan inquiri, observasi, klarifikasi, prediksi dan penentuan terutama dalam mata pelajaran bahasa Inggris. Penggunaan model pembelajaran ini bisa merubah suasana belajar pasif menjadi suasana belajar yang aktif, kreatif, inovatif dan mandiri. Di sampin itu, pembelajaran Discovery Learning juga bisa merubah pembelajaran teacher centered learning menjadi students centered learning. Peran guru sebagai pembimbing untuk mencapai tujuan pembelajaran.Langkah-langkah penerapan model pembelajaran Discovery Learning menurut Syah Ahmad (2004: 24) adalah; 1) guru memberi stimulus (stumulation), 2) mengidentifikasikan masalah (problem statement), 3) mengumpulkan data atau informasi (data collection), 4) mengolah data atau informasi (data processing), 5) 
verifikasi hasil (verification), 6) menarik simpulan (generalization).Kelebihan model pembelajaran Discovery Learning adalah; 1) meningkatkan motivasi, pengetahuan dan keterampilan, baik secara individu maupun kelompok, 2) pengetahuan dan keterampilan yang diperoleh peserat didik akan lebih kuat dan puas, 3) menimbulkan rasa senang dan bangga karena terlibat langsung dalam penemuan, 4) perkembangan pengetahuan peserat didik lebih cepat, 6) menumbuhkan sifat kemandirian yang tinggi, 7) menimbulkan berpikir inisiatif, intuitif, solutif dan kritis, 8) bisa mengembangkan kecakapan dan bakat sehingga terdorong belajar sepanjang hayat. Adapun kelemahan model pembelajaran Discovery Learning adalah: 1) bagi peserta didk berpikir lambat bisa frustasi karena mengalami kesulaitan secara abstrak dan konsep, 2) kurang efisien dalam pembelajaran jika jumlah siswanya cukup banyak, 3) memerlukan waktu relatif lama, 4) dalam mata pelajaran bahasa Inggris, peserta didik dituntut harus mampu memahami ciri kebahasaan setiap genres base text.Model pembelajaran kooperatif Discovery Learning ini sangat sesuai dalam pembelajaran bahasa Inggris dengan materi short functional text seperti; banner, pamphlet leaflet dan language feature (seperti; prepostions, phrases, clauses, word class, dan any tenses) dari tiap jenis genres. Pembelajaran teks banner, pamphlet, leaflet dan language features of genres text lain menuntut kemampuan peserta didik yang jeli dalam hal tenses karena masing-masing teks memiliki kesamaan dan berbedaan dilihat dari struktur teks, tujuan dan ciri kebahasaan. Untuk penerapan model pembelajaran Discovery Learning mata pelajaran bahasa Inggris, para peserta didik harus mampu memahami konsep masingmasing teks. Kemudian mencari contoh teks tertentu guna danalisis untuk mencari data sebanyak-banyaknyas seperti jenis prepostions, tenses, prases dan sebagainya. Data yang diperolah tadi diproses untuk diambil simpulan, sebelum disimpulkan secara umum, hasil proses simpulan diverifikasi bersama. Terakhir simpulan yang sudah melalui verifikasi tersebut dilaporkan.

Kelima, model pembelajaran kooperatif Project Based Learning (PBL). Pembelajaran Project Based Learningadalah model pembelajaran yang menggunakan proyek dalam menyelesaikan suatu Kompetensi Dasar (KD) tertentu.Tidak setiap KD mata pelaajran bahasa Inggris bisa menggunakan model pembelajaran ini. Pembelajaran ini membutuhkan perencanaan matang karena guru harus mempertimbangkan kemanfaatan produk, kemampuan peserta didik, anggaran, waktu yang cukup, keamanan pada saat pembuatan produk, dan rumit tidaknya suatu proyek. Dalam pembelajaran berbasis proyek, peserta didik dan guru harus bekerja sama yang maksimal. Dalam kelompok, peserta didik diharapkan mampu merencanakan secara holistik untuk membuat suatu produk atau proyek yang ditugaskan oleh guru. Di samping itu, mereka juga harus melakukan eksplorasi, penilaian, interpretasi, sintesis dan komunikasi. Pembelajaran Berbasis Proyek merupakan model belajar yang menggunakan masalah sebagai awal dalam mengumpulkan dan mengintegrasikan antara pengetahuan, pengalaman dan keterampilan secara nyata. Pembelajaran Berbasis Proyek dirancang untuk digunakan pada materi-materi yang dipandang kemanfaatan produk atau proyek yang dihasilkan. Pembelajaran ini memberikan kesempatan kepada para peserta didik untuk bekerja sama dengan sungguhsungguh, bekerja sebagai perancang dan memadukan kemampuannya, baik pengetahuan, pengalaman dan keterampilan secara kolaboratif dengan rekan anggota. Ciri pembelajaran berbasis proyek adalah sebagai berikut; 1) kelompok membuat dan merancang perangkat kerja atau jadwal, 2) ada tantangan yang diberikan kepada peserta didik, 3) setiap peserta didik sama-sama bertanggungjawab, 4) proses evaluasi dilakukan secara kontinyu, 5) kelompok melaukan refleksi setiap selesai kegiatan, 6) produk atau hasil proyek dievaluasi 
bersama guru sebagai pembimbing, 7) peran guru sebagai fasilitator dan pembimbing, 8) adanya anggaran untuk pembuatan proyek. Langkah-langkah penerapan Pembelajaran Berbasis Proyek adalah; 1) menentukan pertanyaan mendasar dan nyata yang bisa memberikan gagasan besar dan aktivitas peserta didik, 2) mendesain perencanaan atau menjadwal kegiatan, 3) melaksanakan kegiatan yang sudah dijadwalkan, 4) guru memonetor dan membimbing kegiatan kelompok, 5) kelompok menyerahkan hasil proyek, 6) guru menguji hasil dan menilai untuk mengukur ketercapaian, 7) guru dan perserta didik melakukan refleksi terhadap kegiatan dan hasil proyek. Kelebihan model pembelajaran berbasis proyek adalah; 1) meningkatkan motivasi belajar dan mendorong kemampuan memecahkan suatu masalah, 2) membuat peserta didik lebih aktif, 3) mendorong peserta didik untuk berkolaborasi dan mengembangkan keterampilan komunikasi, 4) memberikan pengalaman kepada peserta didik dalam mengorganisasi proyek, 5) peserta didik ikut terlibat dalam mengambil keputusan. Adapun kelemahan pembelajaran PBL adalah; 1) memakan waktu relatif lama, 2) mengeluarkan dana yang cukup, kurangnya menguasai teknologi atau IT, 3) terkadang adanya perubahan jadwal kegiatan, 4) tidak semua peserta didik berani bereksperimen, 5) adanya peserta didik yang pasif.Model pembelajaran Project Based learning (PBL) ini sangat cocok digunakan dalam pembelajaran mata pelajaran bahasa Inggris materi teks narrative dan review. Salah satu sub materi narrative adalah memahami informasi dan makna cerita teks narrative. Untuk menguatkan pemahaman cerita teks narrative, guru biasanya meminta peserta didik membuat film pendek sederhana dalam kelompok sebagai penilaian keterampilan. Sebelum melakukan kegiatan pembuatan film, guru memberi penjelasan tentang teknik pembuatan film pendek tersebut, seperti tema, pembuatan jadwal, hemat anggaran, properti, lokasi shooting yang aman, rubruk penilaian dan lain-lain. Pengalaman guru dalam penerapan model ini, paling banyak sekali dalam satu semester karena pertimbangan waktu dan biaya. Ternyata hasil filmnya sangat memuaskan dan penyelesaiannya pun sesuai waktu yang sudah dijadwalkan. Berikut di antara hasil produk atau karya proyek film mata pelajaran bahasa Inggris materi teks narrative dari kelas XI MIPA SMA Negeri 1 Gemolong dalam dokumen CD dan yang lainnya dalam dokumen Fleshdisk.

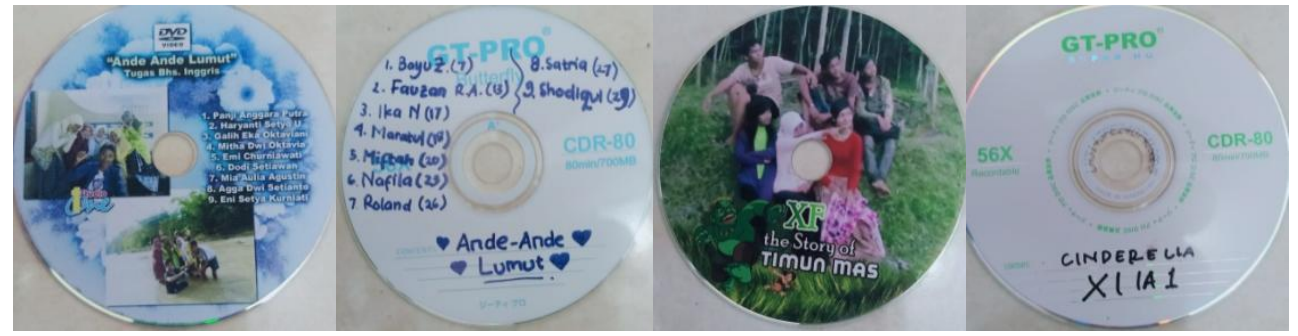

Gambar 1. Produk Film dalam CD

Keenam, model pembelajaran kooperatif Students Teams Achievemnt Division (STAD). Pembelajaran STAD ini juga jenis pembelajaran dengan menggunakan kelompokkelompok kecil yang terdiri dari 4 sampai 6 anggota peserta didik yang bervareasi tingkatan. Pembelajaran ini bisa melatih dan mendorong kerja sama antar anggota agar menguasai atau terampil pada materi yang disampaikan oleh guru. Salvan (dalam Rusman, 2012: 14) mengatakan bahwa model pembelajaran STAD merupakan vareasi pembelajaran kooperatif yang memicu siswa agar saling mendorong dan membantu satu sama lain untuk menguasai keterampilanyang diajarkan oleh guru. Maka dari itu, ciri utama pembelajaran STAD 
adalah kekompakan dalam kerja sama tim.

Tabel 2. Sintaks pembelajaran Students Teams Acheavement Division menurut Nugroho (2009: 4) dalam Sumardi (2020: 25)

\begin{tabular}{|c|c|c|}
\hline FASE & KEGIATAN GURU & KEGIATAN SISWA \\
\hline \begin{tabular}{l}
\multicolumn{1}{c}{ Fase 1 } \\
Menyampaikan \\
tujuan dan \\
memotivasi siswa
\end{tabular} & $\begin{array}{l}\text { Guru menyampaikan semua } \\
\text { tujuan pembelajaran yang } \\
\text { ingin dicapai pada } \\
\text { pembelajaran tersebut dan } \\
\text { memotivasi siswa belajar }\end{array}$ & $\begin{array}{l}\text { Siswa memperhatikan } \\
\text { penjelasan guru tentang } \\
\text { tujuan belajar yang harus } \\
\text { dicapai }\end{array}$ \\
\hline $\begin{array}{l}\quad \text { Fase 2 } \\
\text { Menyajikan } \\
\text { informasi }\end{array}$ & $\begin{array}{l}\text { Guru menyajikan informasi } \\
\text { kepada siswa baik dengan } \\
\text { peragaan maupun teks }\end{array}$ & $\begin{array}{l}\text { Siswa memperhatikan } \\
\text { informasi dan penjelasan } \\
\text { dari guru secara aktif }\end{array}$ \\
\hline \begin{tabular}{l}
\multicolumn{2}{c}{ Fase 3 } \\
Mengorganisasikan \\
siswa ke dalam \\
kelompok-kelompok \\
belajar
\end{tabular} & $\begin{array}{l}\text { Guru menjelaskan pada siswa } \\
\text { bagaimana caranya } \\
\text { membentuk kelompok } \\
\text { belajar dan membantu setiap } \\
\text { kelompok agar melakukan } \\
\text { transisi yang efisien }\end{array}$ & $\begin{array}{l}\text { Siswa membentuk } \\
\text { kelompok-kelompok belajar } \\
\text { dengan bantuan dari guru }\end{array}$ \\
\hline \begin{tabular}{lr}
\multicolumn{1}{c}{ Fase 4 } \\
Membantu & kerja \\
kelompok & dalam \\
belajar &
\end{tabular} & $\begin{array}{ll}\text { Guru membimbing } \\
\text { kelompok-kelompok } \\
\text { pada selajar } \\
\text { mengerjakan tugas } & \text { mereka } \\
\end{array}$ & $\begin{array}{l}\text { Siswa mengerjakan tugas } \\
\text { yang diberikan guru dalam } \\
\text { kelompok-kelompok belajar } \\
\text { yang telah dibentuk }\end{array}$ \\
\hline $\begin{array}{l}\text { Fase } 5 \\
\text { Evaluasi }\end{array}$ & $\begin{array}{l}\text { Guru mengevaluasi hasil } \\
\text { belajar tentang materi yang } \\
\text { telah dipelajari atau masing- } \\
\text { masing } \\
\text { mempresentasikan kelompok } \\
\text { kerjanya }\end{array}$ & $\begin{array}{l}\text { Siswa menerima hasil } \\
\text { evaluasi belajarnya atau } \\
\text { mempresentasikan hasil } \\
\text { kerjanya }\end{array}$ \\
\hline $\begin{array}{l}\text { Fase 6 } \\
\text { Memberikan } \\
\text { penghargaan }\end{array}$ & $\begin{array}{l}\text { Guru mencari cara-cara } \\
\text { untuk menghargai baik upaya } \\
\text { maupun hasil belajar individu } \\
\text { dan kelompok }\end{array}$ & $\begin{array}{lrr}\text { Siswa } & \text { dapat } & \text { termotivasi } \\
\text { untuk } & \text { belajar } & \text { dengan } \\
\text { adanya } & \text { penghargaan } \\
\text { tersebut } & & \end{array}$ \\
\hline
\end{tabular}

Kelebihan model pembelajaran STAD adalah; 1) meningkatkan kecakapan individu, 2) meningkatkan kecakapan kelompok, 3) meningkatkan komitmen kerja sama, 4) menghilangkan prasangka buruk terhadap teman sebaya, 5) tidak bersifat kompetitif, 6) menumbuhkan rasa sosial dan kerja sama yang tinggi. Sedangkan kelemahannya adalah; 1) peserta didik berpikir lambat sering tergantung dengan rekan yang berpikir tinggi, 2) peserta didik berpikir tinggi kadang tidak menggunakan pendapat dari rekan peserta didik berpikir lambat. Model pembelajatan STAD cocok digunakan pembelajaran bahasa Inggris materi keterampilan menulis (writing skill) teks recount. Keterampilan menulis teks recount bagi peserta didik masih rendah, baik secara individu maupun kalsikal atau kelompok. Dengan menggunakan model pembelajaran STAD, peserta didik akan terlatih keberaniannya. Mental mereka akan terbentuk pada saat belajar dan bekerja kelompok. STAD tidak hanya melatih kecakapan dan keterampilan menulis teks recount akan tetapi 
juga keterampilan berbicara (speaking skill). Bagi peserta didik yang rendah diri dan berpikir lambat akan terdorong mentalnya karena mereka harus membangun kerja sama antara satu dengan yang lainnya dalam satu kelompok. Penulis sendiri pernah mengadakan penelitian di kelas X IPS 2 SMA Negeri 1 Gemolong pada tahun pelajaran 2016/2017. Pada saat itu penulis prehatin karena hampir rata-rata peserta didik memiliki keterampilan menulis teks recount masih sangat rendah, terutama berkaitan dengan grammar dan vocabularies (kosa kata). Hal tersebut ditunjukkan dalam persentasi hasil keterampilan menulis siklus I dari 33,3\% menjadi $86,6 \%$ pada siklus II. Selain itu motivasi mental dan keberanian menulis dan berbicara bahasa Inggris juga meningkat.

Ketujuh, model pembelajaran kooperatif Talking Stick. Model pembelajaran Talking Stick sebuah pembelajaran yang dapat membantu peserta didik yang pasif di kelas. Pembelajaran ini biasanya dilakukan dengan kelompok. Guru harus membentuk kelompok belajar di mana tiap-tiap kelompok terdiri dari 4 sampai 6 anggota peserta didik. Guru harus menjelaskan cara permainan pembelajaran ini dengan baik sebelum permaianan dimulai. Pembelajaran ini sangat menyenangkan dan membuat suasana kelas menjadi lebih hidup karena pada proses permainan diiringi dengan musik. Fungsi musik ini untuk membuat situasi pembelajaran lebih santai, releks dan menghibur. Kedua jika guru menghentikan musik dan bagi peserta didik atau anggota yang memegang tongkat bicara (talking stick), maka dia harus berbicara atau menjawab bahasa Inggris sesuai materinya. Oleh karena iti, setiap anggota harus memahami langkah-langkah permainan pembelajaran Talking Stick dengan baik. Menurut Ramadhan (2010:115-116) dalam Sumardi (2019: 74) langkah-langkah pembelaajran Talking Stick diantaranya; 1) guru membentuk kelompok belajar, 2) guru menyiapkan Talking Stick yang panjangnya $20 \mathrm{~cm}$ sejumlah kelompok, 3) guru menyampaikan materi secara singkat, 4) anggota kelompok berdiskusi membahas materi dengan matang, 5) guru memanggil ketua kelompok untuk mengambil tongkat bicara, 6) guru memutar musik sebagai tanda permaian pembelajaran dimulai, 7) sambil mengawasi peserta didik, guru menghentikan musik secara periodik hingga masing-masing anggota berbicara atau menjawab semua, 8) guru memberi simpulan, 9) guru beserta peserta didik melakukan refleksi, penilaian dan evaluasi, 10) guru menutup pembelajaran. Kelebihan model pembelajaran Talking Stick adalah; 1) menguji kesiapan peserta didik, 2) melatih peserta didik mampu memahami materi dengan cepat, 3) mendorong peserta didik untuk belajar lebih giat dan sungguh-sungguh karena sewaktu-waktu musik berhenti dan tongkat berada ditangannya, ia harus menjawab atau berbicara bahasa Inggris, 4) setiap peserta didik termotivasi dan berani bicara bahasa Inggris. Sedangkan kelemahannya adalah; 1) membuat peserta didik senam jantung, 2) peserta didik yang kurang siap, tidak bisa menjawab dengan benar, 3) membuat peserta didik berpikir tegang, 4) ketakutan akan pertanyaan atau giliran berbicara bahasa Inggris secara spontan.Model pembelajaran Talking Stick ini sangat cocok digunakan untuk pembelajaran peningkatan motivasi belajar dan keterampilan berbicara (speaking) dalam teks recount. Pembelajaran ini sangat sesuai untuk mengatasi kelas kurang aktif. Di samping itu, pembelajaran Talking Stick juga sangat cocok untuk mengatasi peserta didik yang pasif, malu, takut salah berbicara bahasa Inggris. Pembelajaran ini membuat suasana kelas menjadi lebih hidup dan aktif. Semua peserta didik sangat antusias dan senang dalam mengikuti proses pembelajaran. Setiap peserta didik yang memegang tongkat bicara (talking stick) saat pembelajaran, dia akan langsung berbicara dengan bahasa Inggris sesuai materinya. Rekan satu kelompok bisa membimbing kepada rekannya yang mengalami kesulitan. Penulis sering menggunakan model pembelajaran Talking Stick. Penulis juga pernah mengadakan penelitian di SMA Negeri 1 
Gemolong tahun 2018 yang berjudul Peningkatan Motivasi Belajar dan Keterampilan Speaking dalam Pembelajaran Teks Recount dengan Menggunakan Model Pembelajaran Talking Stick Ke;as X IPS 2 SMA Negeri Gemolong Semester Genap Tahun Pelajaran 2018/2019. Hasil menunjukkan nilai kondisi awal, adalah 43,23 meningkat menjadi 70,18 atau $62,34 \%$ di siklus I dan 79,43 atau $13,18 \%$ di siklus II. Nilai tertinggi dari dari kondisi awal 80,48 meningkat menjadi 85,31atau $6,00 \%$ di siklus I dan 92,30 atau $8,19 \%$ di siklus II. Sementara nilai rata-rata kondisi awal 68,21 meningkat menjadi 77,33 atau $13,37 \%$ di siklus I dan 80,5 atau $4,10 \%$ di siklus II. Berikut sebagaian gambar kegiatan pembelajaran Talking Stick;

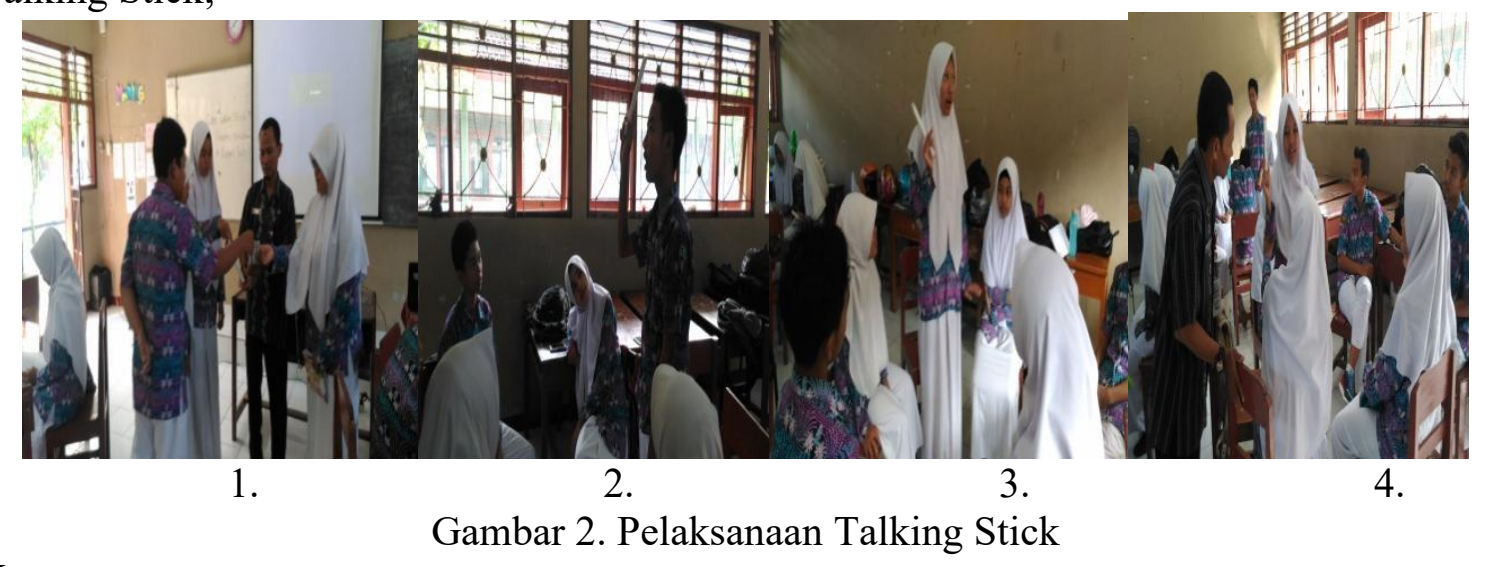

Keterangan:

Gambar 1: perwakilan kelompok mengambil Talking Stick

Gambar 2 dan 3 : salah satu anggota yang memegang Talking Stick sedang berbicara bahasa Inggris teks recount

Gambar 4: guru mengamati kebenaran cerita teks recount yang disampaikan anggota

\section{Strategi Pembelajaran}

Pembelajaran salah tugas pokok bagi guru untuk membelajarkan suatu materi kepada peserta didik. Strategi pembelajaran adalah cara-cara yang yang dipilih dan digunakan oleh seorang guru untuk menyampaikan materi pembelajaran yang bertujuan untuk memudahkan peserta didik dalam menerima dan memahami materi pembelajaran. Jika peserta didik mampu memahami materi pembelajaran, mereka diharapkan mampu mencapai tujuan pembelajaran tersebut. Agar tujuan pembelajaran tercapai, maka guru harus memiliki keterampilan dalam strategi pembelajaran, termasuk memilih model pembelajarannya. Model pembelajaran yang dipilih oleh guru merupakan seperangkat kebijakan untuk menentukan tujuan pembelajaran. Di samping itu, strategi pembelajaran dipilih karena alasan agar pembelajaran lebih menyenangkan, lebih efektif dan juga lebih mudah diterima oleh peserta didik. Oxford (1990: 8) mendefinisikan bahwa strategi pembelajaran sebagai "specific actions taken the learner to make learning easier, fastre, more enjoyable, more self-directed, more effective, and more transfereable to new sutautuins". Sedangkan Sanjaya (2006) menuliskan strategi pembelajaran sebagai rencana tindakan atau rangkaian kegiatan termasuk penggunaan metode dan pemanfaatan berbagai sumber daya atau kekuatan dalam pembelajaran. Kamp (1995) menyampaikan strategi pembelajaran adalah suatu kegiatan pembelajaran yang harus dikerjakan oleh guru dan siswa agar tujuan pembelajaran dapat dicapai secara efektif dan efisien.Berdasarkan pendapat-pendapat tersebut dapat ditarik pengertian bahwa strategi pembelajaran 
merupakan sebuah rangkaiankegiatanpembelajaran yang direncanakan oleh guru dan diikuti oleh siswa untuk melaksanakan pembelajaran tertentu dengan menggunakan metode, model, materi, sumber, media dan prosedur yang disusun secara efektif, efisien dan menyenangkan untuk mencapai tujuan pembelajaran. Pemilihan model pembelajaran kooperatif dan menyenangkan bagi guru merupakan bagian dari strategi pembelajaran yang dilakukannya. Oleh karen itu, seorang guru dituntut terampil, cermat dan selektif dalam memilih model pembelajaran yang paling cocok dengan materi yang akan disampaikan kepada peserta didiknya. Penggunaan model pembelajaran yang tepat akan mempengaruhi peserta didik dalam mengikuti kegiatan pembelajaran dan hasil pembelajaran. Model pembelajaran yang baik adalah pembelajaran yang sesuai dengan kondisi lingkungan dan karakter peserta didik serta lebih banyak melibatkan peran serta peserta didik (students centered) dalam kegiatan pembelajaran.

\section{Simpulan dan Saran}

Semua jenis model pembelajaran memiliki sintaks atau langkah-langkah penerapan dan media yang berbeda. Kedua, setiap model pembelajaran memiliki kelebihan dan kelemahan masing-masing. Ketiga, semua model pembelajaran bermuara pada kegiatan aktivitas peserta didik (students centered). Penggunaan model pembelajaran kooperatif ini sangat cocok diterapkan dalam pembelajaran tatap muka karena jika diterapkan dengan benar dan sungguh-sungguh, maka suasan kelas menjadi hidup dan pembelajaran bisa berlangsung menarik dan menyenangkan (terutama pembelajaran tatap muka). Pemilihan model pembelajaran yang tepat merupakan bagian strategi pembelajaran yang harus dilakukan oleg guru untuk mencapai tujuan pembelajarannya. Bagi sebagian guru, pemilihan jenis model pembelajaran biasanya dilakukan setelah guru merasa hasil pembelajaran materi tertentu kurang sesuai dengan tujuan. Hal tersebut juga dilakukan oleh penulis. Penulis sudah menggunakan beberapa model pembelajaran yang dipaparkan di atas, seperti model pembelajaran, STAD, Talking Stick, Jigsaw, Talking Chips dan PBL. Hasil pembelajaran dengan menggunakan model-model pembelajaran tersebut sangat signifikan.

Saran penulis setelah mengetahui simpulan ialah 1) pilihlah jenis model pembelajaran yang paling sesuai dengan meteri, 2) pilihlah model pembelajaran yang sesuai dengan karakter peserta didik dan lingkungan, 3) pilihlah model pembelajaran yang lebih efektif, efisien dan praktis, 4) pilihlah model pembelajaran yang memiliki resiko atau kelemahan yang minim, 5) sampaikan prosedur operasional secara jelas model pembelajaran yang akan digunakan kepada peserta didik terlebih dahulu, 6) berilah suatu apresiasi kepada peserta didik. Jika pembelajaran berlangsung jarak jauh (PJJ), maka pilihlah jenis model pembelajaran yang praktis, efektif dan efisien yang bisa digunakan ke dalam aplikasi zoom.

\section{Daftar Rujukan}

Ahmad, Syah. (2005). Strtegi Belajar Mengajar. Jakarta: Ciputat Press. Anita, 2010. Cooperative Learning (Mempraktekan Cooperative Learning di Ruang-Ruang Kelas). Jakarta: Grasindo

Budiningsih. (2005). Model Discovery Learning. Jakarta: Pustaka Mandiri.

Giyono. (2019) Penerapan Metode Group Investigation untuk meningkatkan Motivasi dan Kemampuan Menganalisis Teks Negosiasi Peserta Didik Kelas X MIPA 1 SMA Negeri 1 gemolong Tahun Pelajaran 2018/2019. Jurnal Pendidikan, volume 28(1) 
Maret 2019, hal: 1-16.

Kemp.(1995). Proses Perancangan Pengajaran. Bandung: ITB.

Piaget, J. (1963). The Origins of Intelligence in Children. New York: W.W. Norton \& Company, Inc.

Oxford, R. L. (1990). Language Learning Strategies: WliatEveiy Teacher Should Know. New York: Newbury House.

Rusman. (2014). Model-model Pembelajaran (Mengembangkan Profesionalisme Guru). Jakarta: Raja Grafindo Persada.

Sanjaya, Wina. (2006). Perencanaan dan Desain Sistem Pembelajaran. Jakarta: Medi GroupSlameto.

Sanjaya, W. (2006). Strategi Pembelajaran. Jakarta: Kencana Prenada Media Group.

Sumardi. (2019) Peningkatan Motivasi Belajar dan Keterampilan 'Speaking' dalam Teks 'Recount' dengan Menggunakan Model Talking Stick Kelas X IPS 2 SMA Negeri 1Gemolong Semester GenapTahun Pelajaran 2018/2019. Jurnal Pendidikan, volume 28(1), Maret 2019, hal: 71-80.

Sumardi. (2020) Apakah Melalui Media Audio Visual dan Model STAD (Students Teams Acheavement Division) dapat Meningkatkan Motivasi dan Hasil Belajar Bahasa Inggris (Knowledge and Writing Skill) Teks Recount Kelas X IPS 2 SMA Negeri 1 Gemolong Kabupaten Sragen Semester 1 Tahun Pelajaran 2016/2017). Jurnal Pendidikan, volume 29(1), Maret 2020, hal: 21-36.

Sardiman, A.M. (2003). Interaksi Dan Motivasi Belajar Siswa. Jakarta: PT. Rajawali Pres Grafindo Persada.

Marsela. (2012). Model Pembelajaran Kancing Gemerincing. Diambil dari: http://metra2277.blogspot.com/2012/10/model-pembelajaran-kancinggemerincing.

Supriono, Agus. (2010). Cooperative Learning Teori dan Aplikasi PAIKEM. Yokyakarta: Pustaka Belajar

Trianto. (2007). Model-Model Pembelajaran Inovatif Berorientasi Konstruktifistik. Jakarta: Prestasi Pustaka Publisher. 